\title{
MASALAH ANAK PENDEK DI INDONESIA DAN IMPLIKASINYA TERHADAP KEMAJUAN NEGARA
}

\author{
Atmarita \\ Pusat Teknologi Intervensi Kesehatan Masyarakat, Badan Litbangkes \\ atmarita@gmail.com
}

\begin{abstract}
ABSTRAK
Masalah gizi khronis di Indonesia terlihat jelas ditandai dengan prevalensi anak pendek usia 0-59 bulan yang mendekati 40 persen. Kajian ini bertujuan untuk memberikan rekomendasi konkrit berdasarkan faktor penyebab terjadinya masalah gizi khronis. Analisis deskriptif dilakukan dari hasil pengumpulan data Riset Kesehatan Dasar 2010. Kajian menunjukkan dengan jelas bahwa anak Indonesia masih jauh tertinggal ditandai dengan pencapaian rata-rata tinggi badan ketika mereka berusia 19 tahun. Pada anak laki-laki adalah 162,9 cm, lebih pendek 13,6 cm dibanding rujukan, dan pada anak perempuan adalah $152,8 \mathrm{~cm}$ atau $10,4 \mathrm{~cm}$ lebih pendek dibanding rujukan. Terhambatnya pertumbuhan pada anak mengindikasikan pembangunan yang kurang efisien dalam upaya perbaikan sumber daya manusia. Perlu dilakukan upaya komprehensif dan terintegrasi mulai dari mengatasi akar permasalahan terkait kemiskinan melalui berbagai bentuk upaya pemberdayaan masyarakat, termasuk perubahan perilakunya yang dapat mempercepat perbaikan permasalahan yang saat ini terjadi.
\end{abstract}

Kata kunci: masalah, anak pendek, kemajuan negara

\section{ABSTRACT}

\section{THE PROBLEM OF STUNTED CHILDREN IN INDONESIA AND ITS IMPLICATION FOR THE COUNTRY IMPROVEMENT}

Chronic malnutrition problems in Indonesia are illustrated by the high prevalence of short children aged 0-59 months which closed to 40 percent. This paper attempts to provide concrete recommendations based on identified risk factors for chronic malnutrition, namely stunting. The analysis was using data collected from Basic Health Research (Riskesdas) 2010. Based on the data, children in Indonesia are still far behind in nutritional attainment as shown by the achievement of average height of children when they are 19 years old. Among males attained a mean height of $162.9 \mathrm{~cm}$, which is $13.6 \mathrm{~cm}$ shorter than international WHO reference mean height at the same age and 19 year old girls had a mean height of $152.8 \mathrm{~cm}$ or $10.4 \mathrm{~cm}$ shorter than the WHO height reference. Impaired growth during childhood indicates less efficient development especially in the improvement of human resources. Comprehensive and integrated efforts should be urgently needed and started from the root causes of poverty affecting nutritional intake through various forms of community empowerment, including behavior changes which stimulates intervention program acceleration to combat stunting risk.

Keywords: problem, stunted children, country improvement

\section{PENDAHULUAN}

$\mathrm{M}$ asalah gizi, terutama anak pendek tersebar di seluruh wilayah dengan disparitas yang sangat lebar dari yang terendah 29,1 persen di Kepulauan Riau sampai yang tertinggi 61,2 persen di Nusa Tenggara Timur (hasil Riset Kesehatan Dasar/Riskesdas 2010).1 Kejadian gagal tumbuh yang terjadi pada usia balita akan berlanjut ke usia berikutnya. Besar kemungkinan ketika mereka menginjak usia 19 tahun, maka tinggi badan optimal tidak tercapai. Mereka akan menjadi manusia dewasa yang pendek dengan keterbatasan untuk berproduktivitas optimal. Dari hasil Riskesdas 2010 masalah ini cukup jelas yang memberikan gambaran masih tingginya perempuan usia 15-19 tahun yang tidak lagi meneruskan sekolah dan masuk pada usia reproduksi yang 
selanjutnya melahirkan lagi anak-anak yang kurang gizi.

Komitmen nasional untuk mengatasi masalah gizi di Indonesia sudah cukup baik, karena sudah menjadi bagian dari misi nasional 'Mewujudkan bangsa yang berdaya saing' tertulis pada dokumen Rencana Pembangunan Jangka Panjang Nasional/RPJPN 2005-2025 (UU 17/2007 tentang RPJPN 2005-2025). Jelas sekali untuk mewujudkan misi tersebut, perlu dilakukan upaya-upaya yang bertujuan untuk meningkatkan kualitas sumber daya manusianya.

Apa yang terjadi di Indonesia? Kejadian anak pendek merupakan gambaran yang jelas dari tidak berlangsungnya efektivitas pembangunan manusia yang terjadi di tingkat masyarakat sebagai target dari program. Seharusnya sudah banyak bentuk intervensi yang sebenarnya layak dan berhasil guna dapat meningkatkan status gizi ibu dan anak, akan tetapi pada kenyataannya belum berhasil merubah situasi khronis yang terjadi di Indonesia.

Uraian berikut ini merupakan kajian deskriptif dari data Riset Kesehatan Dasar (Riskesdas) 2010 untuk memberikan ilustrasi dan masukan untuk perbaikan situasi Indonesia untuk masa mendatang.

\section{METODE PENELITIAN}

Riskesdas adalah sebuah survei yang dilakukan secara cross sectional. Riskesdas dilakukan secara berkala oleh Badan Penelitian dan Pengembangan Kesehatan (Litbangkes), Kementerian
Kesehatan. Pertama kali dilaksanakan pada tahun 2007, dan berikutnya adalah tahun 2010. Disain Riskesdas 2010 sedikit berbeda dalam hal jumlah sampel dengan Riskesdas 2007. Pada tahun 2010 data dikumpulkan untuk menilai beberapa indikator Millenium Development Goals/MDGs bidang kesehatan. ${ }^{1}$

Sampel Riskesdas 2010 mewakili penduduk Indonesia tingkat nasional dan provinsi. Pemilihan sampel dilakukan sepenuhnya oleh Badan Pusat Statistik (BPS) yang memilih 2800 Blok Sensus (BS) baru berdasarkan Sensus Penduduk (SP) 2010. Pemilihan BS dilakukan berdasarkan status ekonomi, rasio perkotaan/perdesaan, dan juga prevalensi malaria/TB-paru hasil Riskesdas 2007. Dua ribu delapan ratus (2800) Blok Sensus (BS) tersebar dengan ketentuan sampel yang dapat mewakili populasi di 33 provinsi. Selanjutnya dari setiap BS dipilih secara acak 25 (dua puluh lima) rumah tangga, dan dari rumah tangga terpilih, seluruh anggota rumah tangga menjadi sampel untuk dikumpulkan informasi terkait indikator kesehatan. ${ }^{1,2}$

Pengumpulan data dilakukan serentak pada bulan Mei-Juli 2010 oleh pengumpul data yang berpendidikan minimal D3 bidang kesehatan dan berdomisili di wilayah dimana data dikumpulkan. Pengumpul data mendapat pelatihan dari para peneliti Badan Litbangkes. Secara keseluruhan jumlah sampel rumah tangga Riskesdas 2010 adalah 69.300 dengan 251.388 anggota rumah tangga. Distribusi sampel menurut kelompok umur dan jenis kelamin dapat dilihat pada Tabel 1.

Tabel 1

Persentase Distribusi Sampel Riskesdas 2010 menurut Kelompok Umur dan Jenis Kelamin

\begin{tabular}{lccc}
\hline $\begin{array}{l}\text { Kelompok Umur } \\
\text { (Tahun) }\end{array}$ & Laki-laki & Perempuan & Total \\
\hline $0-4$ & 4,5 & 4,2 & 8,8 \\
$5-9$ & 5,4 & 5,1 & 10,5 \\
$10-14$ & 5,1 & 4,6 & 9,7 \\
$15-19$ & 4,2 & 3,9 & 8,1 \\
$20-24$ & 3,5 & 3,7 & 7,2 \\
$25-29$ & 4,0 & 4,3 & 8,4 \\
$30-34$ & 4,0 & 4,2 & 8,2
\end{tabular}




\begin{tabular}{lccc}
$35-39$ & 3,9 & 4,0 & 7,9 \\
$40-44$ & 3,6 & 3,7 & 7,3 \\
$45-49$ & 3,2 & 3,2 & 6,4 \\
$50-54$ & 2,7 & 2,5 & 5,2 \\
$55-59$ & 2,1 & 1,8 & 3,9 \\
$60-64$ & 1,4 & 1,7 & 3,1 \\
$65+$ & 2,6 & 2,9 & 5,5 \\
\hline Total & 50,3 & 49,7 & 100,0 \\
\hline
\end{tabular}

Pada kajian ini, analisis menggunakan sampel anak balita 0-59 bulan $(n=22.296)$ dengan karakteristik seperti tercantum pada Tabel 2. Analisis juga mengungkapkan beberapa faktor terkait yang menyebabkan masalah ini terjadi, terutama dari orangtua/ibu pada anak yang bersangkutan.

Indikator yang digunakan untuk análisis adalah: 1) Prevalensi Anak Pendek (indeks Tinggi Badan menurut umur: <2SD); 2) Rata-rata tinggi badan anak 5-19 tahun; 3) Rata-rata tinggi badan Ibu balita;
4) Berat Badan Lahir/BBL; 5) Cakupan pelayanan kesehatan: penolong persalinan, penimbangan bayi kurun waktu 48 jam, kunjungan neonatus, persen Imunisasi, pemantauan pertumbuhan 6 bulan terakhir, pemberian kapsul vitamin $A ; 6$ ) indikator yang memperburuk kondisi anak: merokok, pernikahan muda, asupan energi/protein yang tidak cukup; 7) kemiskinan menurut tingkat pengeluaran rumah tangga, rasio pengeluaran makanan terhadap total pengeluaran.

Tabel 2

Distribusi Sampel menurut Karakteristik Anak balita

\begin{tabular}{lc}
\hline Karakteristik & $\%$ \\
\hline Tempat Tinggal & \\
Perkotaan & 50,8 \\
Perdesaan & 49,2 \\
Pendidikan Orang Tua & \\
$\quad$ Tidak sekolah/tidak tmt SD & 17,1 \\
Tamat SD/MI & 29,8 \\
Tamat SLTP/MTS & 18,4 \\
Tamat SLTA/MA & 26,3 \\
Tamat D1/D2/D3/PT & 8,4 \\
Pekerjaan Orang Tua & \\
Tidak kerja/Sekolah & 4,4 \\
Petani/Nelayan/Buruh & 46,4 \\
Wiraswasta/Jasa/Dagang & 37,7 \\
PNS/TNI/Pegawai/lainnya & 11,4 \\
Tingkat Pengeluaran Orang Tua/Bulan & \\
Kuintil 1 (Terbawah) & 26,4 \\
Kuintil 2 (Menengah Bawah) & 22,4 \\
Kuintil 3 (Menengah) & 20,1 \\
Kuintil 4 (Menengah Atas) & 17,5 \\
Kuintil 5 (Teratas) & 13,5 \\
\hline
\end{tabular}

\section{BESARAN MASALAH GIZI}

Jumlah penduduk Indonesia berdasarkan Sensus Penduduk 2010 sudah mencapai 237,56 juta yang tersebar di 33 provinsi dengan laju pertumbuhan penduduk sebesar 1,49. Tahun 2010, proporsi anak 0-4 tahun adalah 8,8 persen, 
dan anak 5-14 tahun adalah 20,2 persen. ${ }^{3}$ Mereka adalah calon generasi penerus yang akan membangun dan merubah Indonesia pada kurun waktu setelah tahun 2025. Pada tahun 2025, diperkirakan proporsi kelompok usia muda akan menurun, dan penduduk akan mencapai umur yang lebih tua. Pada tahun 2025, diperkirakan proporsi anak 0-4 tahun akan menjadi 7,3 persen dan anak usia 5-14 tahun menjadi 15 persen. Sementara usia 65 tahun keatas akan menjadi 9,2 persen pada tahun 2025, dimana pada tahun 2010 sudah 5,5 persen.

Pertanyaan mendasar, mampukah 20,2 persen anak ini membawa Indonesia ke situasi yang jauh lebih baik pada tahun 2025? Visi, misi, kebijakan dan strategi yang tercantum pada RPJPN 2005-2025 perlu diterjemahkan ke aplikasi program yang bisa mendarat di masyarakat secara luas agar tercipta generasi penerus bangsa yang dapat bersaing global. ${ }^{4}$

Seperti yang terlihat pada Gambar 1, Indonesia yang menghadapi besarnya masalah anak pendek menunjukkan karena masih banyaknya bayi lahir dengan berat badan rendah. Mereka mengalami gagal tumbuh pada usia balita dan menjadi remaja dan dewasa/pendek, dan jika remaja/dewasa ini hamil akan melahirkan lagi bayi dengan berat badan rendah, dan seterusnya. Ilustrasi ini sebenarnya telah diperkenalkan semenjak tahun 1992 (ACC/SCN 1992) menunjukkan masalah inter generasi yang terlihat jelas terjadi di Indonesia. ${ }^{5}$

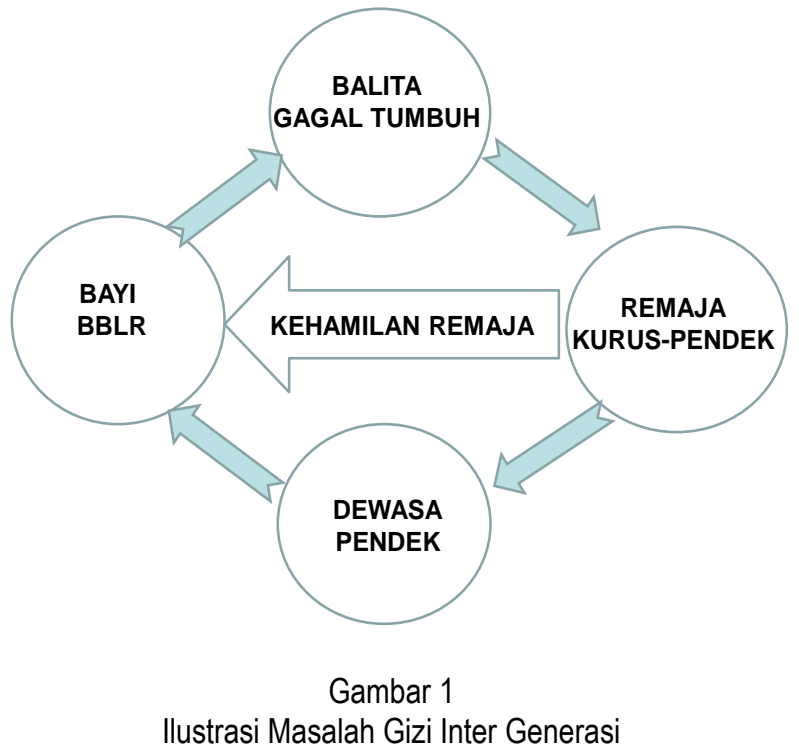

Secara nasional dikatakan bahwa prevalensi anak pendek (indeks tinggi badan menurut umur, TB/U di bawah -2 simpang baku /- 2SD) adalah 35,6 persen. Berdasarkan kelompok umur dan jenis kelamin, prevalensi anak pendek adalah berkisar antara 30 persen pada bayi $0-11$ bulan.
Ada kecenderungan angka prevalensinya meningkat sejalan dengan bertambahnya umur dan umumnya anaklaki-laki lebih bermasalah dibanding anak perempuan (Gambar 2). Kondisi ini mencerminkan proses tumbuh kembang yang sebenarnya sudah tidak baik semenjak masih dalam kandungan. 


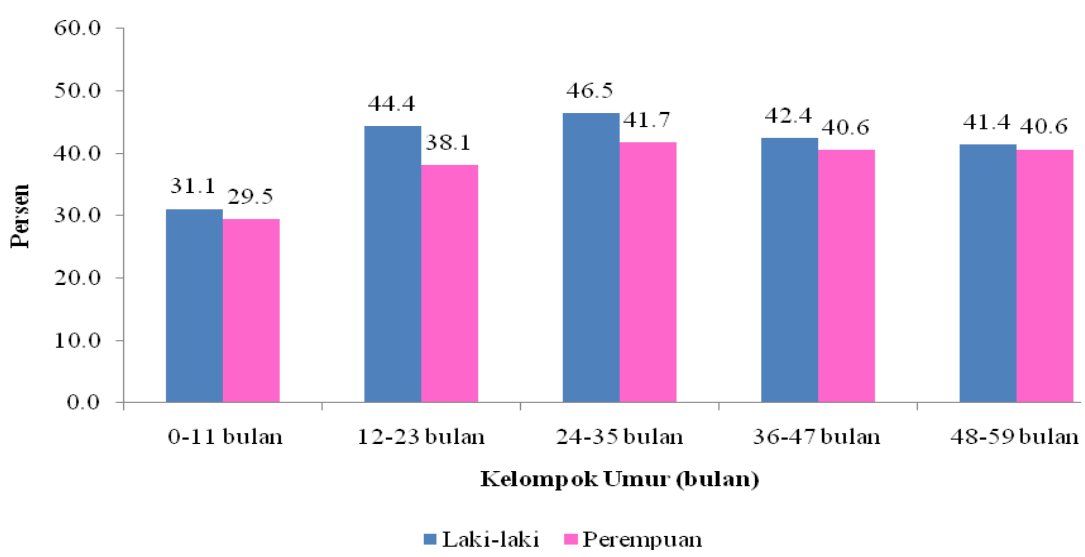

Gambar 2

Prevalensi Pendek (TB/U <-2SD) pada Balita menurut Kelompok Umur dan Jenis Kelamin, Riskesdas 2010

Gangguan pertumbuhan anak balita terlihat dengan jika rata-rata tinggi badannya dibandingkan dengan rujukan.., 6 Pada anak laki-laki perbedaan itu sampai $6,7 \mathrm{~cm}$ ketika menginjak usia 59 bulan, dan pada anak perempuan untuk usia yang sama perbedaannya $7,3 \mathrm{~cm}$ dari rujukan (Gambar 3). Secara kumulatif gangguan pertumbuhan pada usia balita akan berdampak pada usia berikutnya, Pada anak laki-laki, rata-rata tinggi badan yang bisa dicapai adalah $162,9 \mathrm{~cm}$ pada usia 19 tahun, lebih pendek $13,6 \mathrm{~cm}$ dibanding rujukan. Demikian juga pada anak perempuan rata-rata tinggi badan yang bisa dicapai pada usia 19 tahun adalah 152,8 $\mathrm{cm}$ atau lebih pendek $10,4 \mathrm{~cm}$ dibanding rujukan. ${ }^{5,7}$ (Gambar 4)
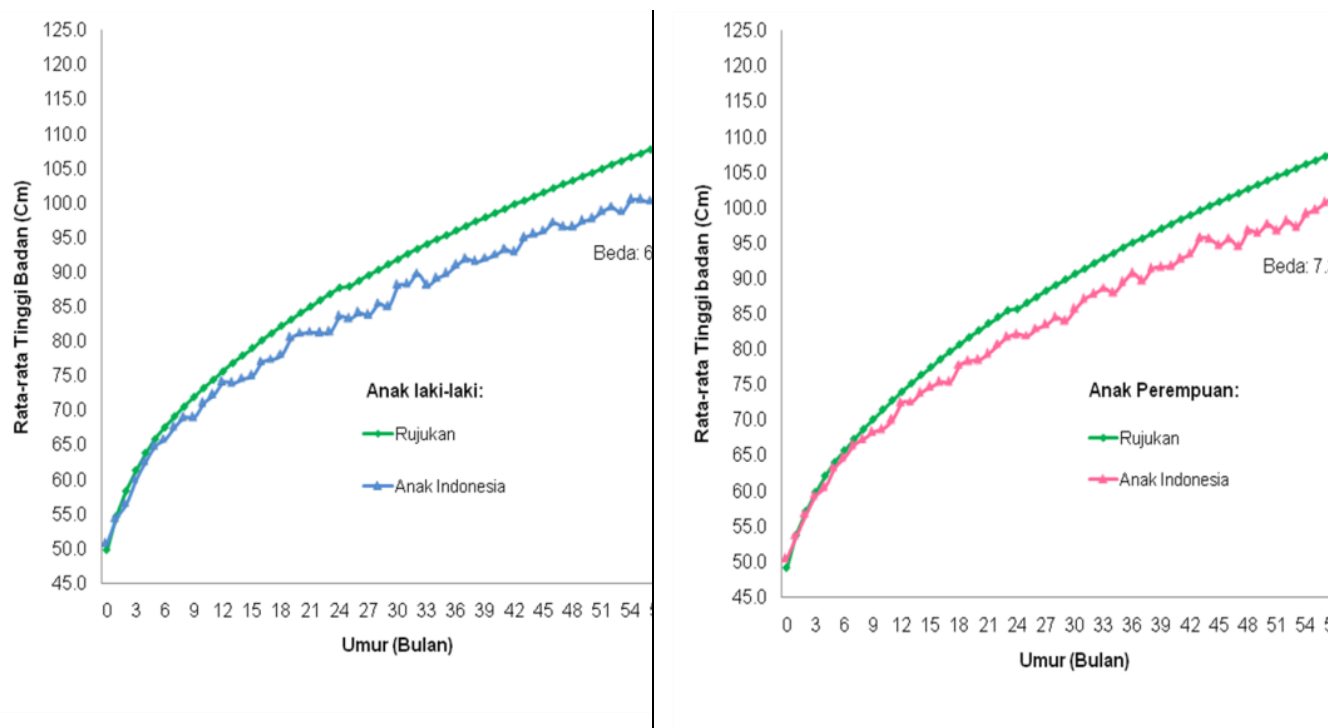

Gambar 3

Rata-rata Tinggi Badan Anak Balita Indonesia: Laki-laki dan Perempuan dibanding Rerata Tinggi Badan Rujukan WHO 2005 

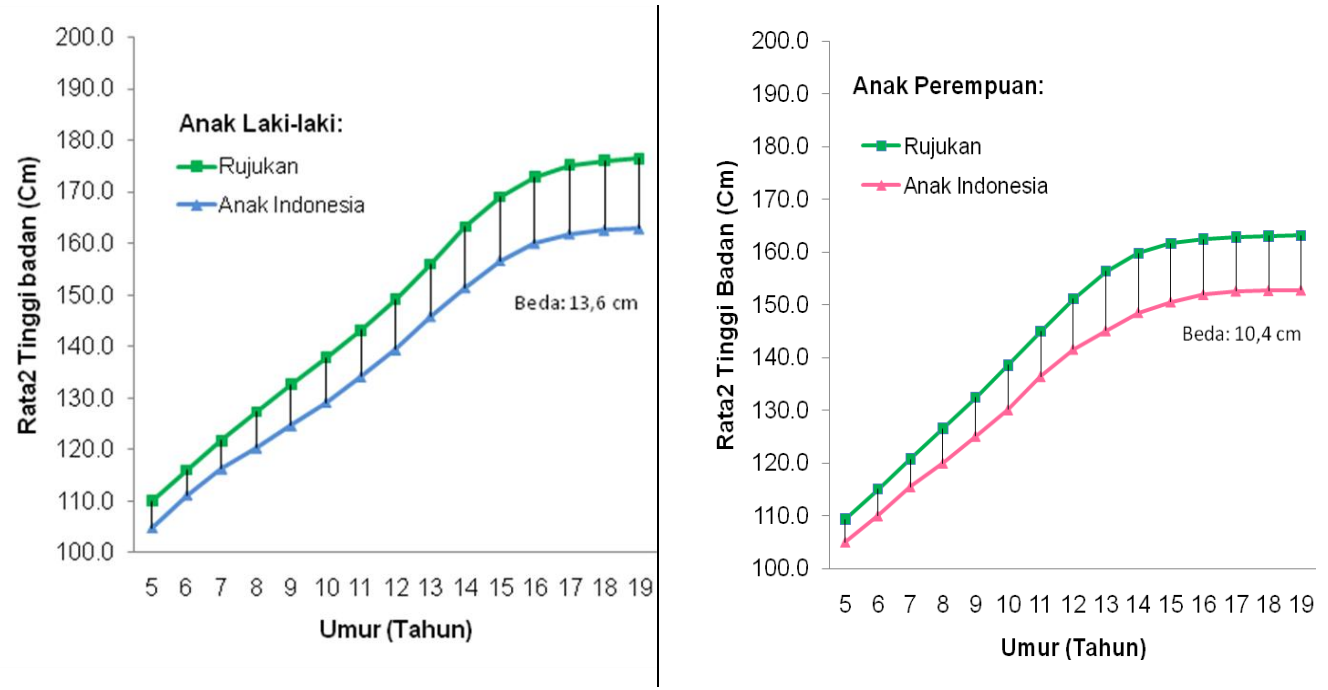

Gambar 4

Tinggi Badan Rata-rata Anak Indonesia Usia 5-19 tahun: Laki-laki dan Perempuan dibanding Tinggi Badan Rata-rata Rujukan WHO 2007

Seperti ilustrasi pada Gambar 1, perbedaan rata-rata tinggi badan Ibu Gambar 3 dan 4 menunjukkan anak pendek ini pada umumnya lahir dari ibu sebesar $1,4 \mathrm{~cm}$ antara kelompok anak yang juga pendek. Gambar 5 menunjukkan pendek dan normal $(p=0,000)$.

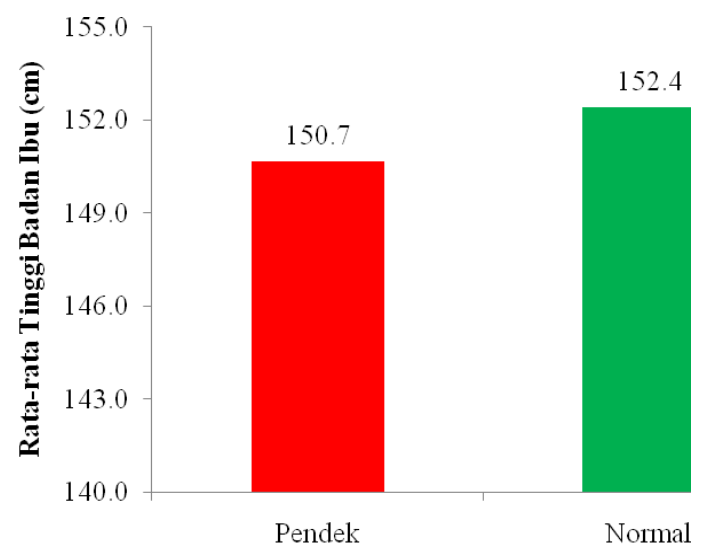

Status Gizi Anak 0-59 bulan

Gambar 5

Rata-rata tinggi badan Ibu menurut Status Gizi Anak 0-59 bulan

Pada Gambar 6 dapat dilihat dengan jelas sekitar $60 \%$ kejadian anak pendek banyak dijumpai pada ibu yang juga pendek (OR: 1,59; $p=0.000$ ). Perbedaan besaran masalahnya juga terlihat dimana prevalensi anak pendek pada ibu-ibu dengan rata-rata tinggi badan $<150 \mathrm{~cm}$ adalah 47,2 persen dibanding ibu-ibu dengan rata-rata tinggi badan $>150 \mathrm{~cm}$ $(36,0 \%)$. 


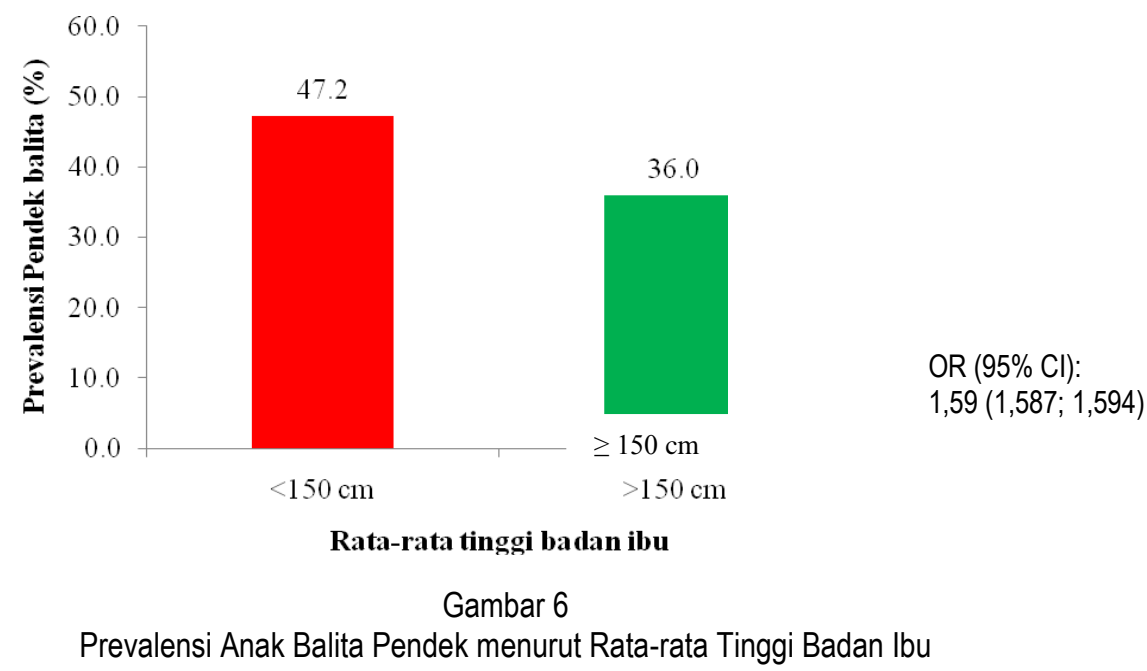

\section{PENYEBAB MENDASAR MASALAH GIZI}

Masih dominannya kejadian anak pendek pada penduduk besar kemungkinan merupakan dampak dari kelaparan yang terjadi dalam waktu lama. ${ }^{8}$ Penyebab yang mendasar antara lain adalah kemiskinan. Perbedaan yang jelas $(p<0.000)$ yang ditunjukkan Gambar 7 , dimana prevalensi masalah gizi pada kelompok penduduk dengan tingkat pengeluaran terendah (kuintil 1) hampir 20 persen dibanding penduduk dengan tingkat pengeluaran teratas (kuintil 5). Perbedaan prevalensi yang mencolok antara kelompok penduduk kuintil 1-4 dengan penduduk kuintil 5 dengan jelas ditunjukkan dari ratarata pengeluaran per kapita yang juga sangat mencolok: < Rp700.000 dan >Rp 1.500.000 (Gambar 8).

Gambaran status ekonomi seperti ini sebenarnya merupakan interaksi dari masalah kurang gizi yang menyebabkan kemiskinan, dan sebaliknya kemiskinan menyebabkan masalah kurang gizi khronis. ${ }^{4}$ Pada usia dewasa, mereka berpotensi untuk tidak optimal berproduktivitas, dan umumnya kondisi ini diikuti juga dengan kecerdasaan yang tidak sempurna. ${ }^{9}$

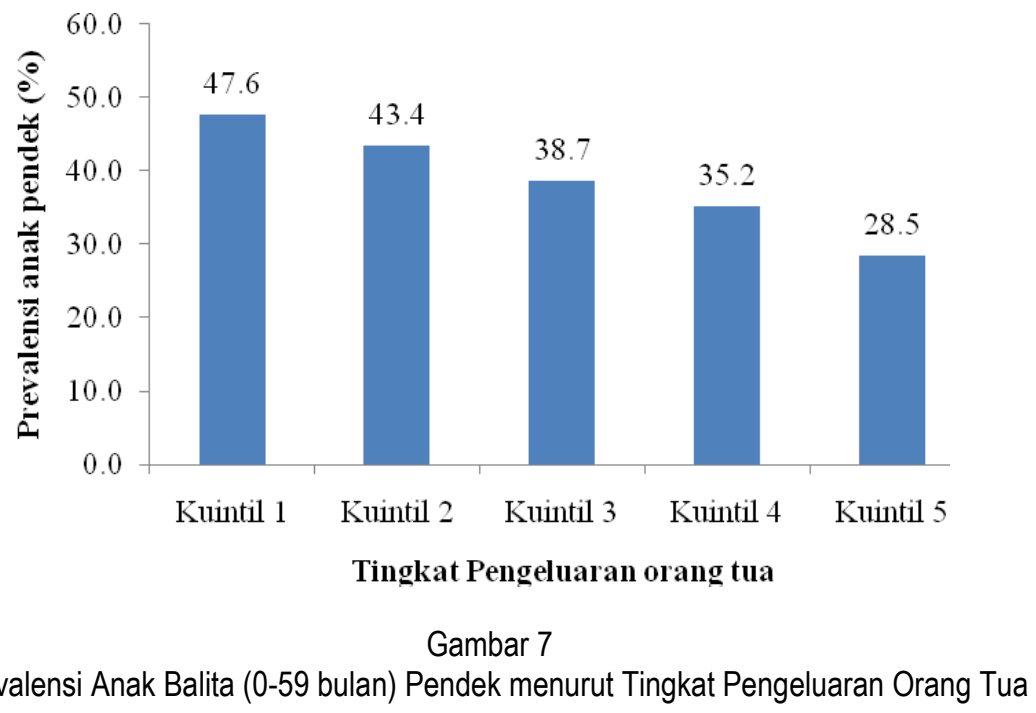




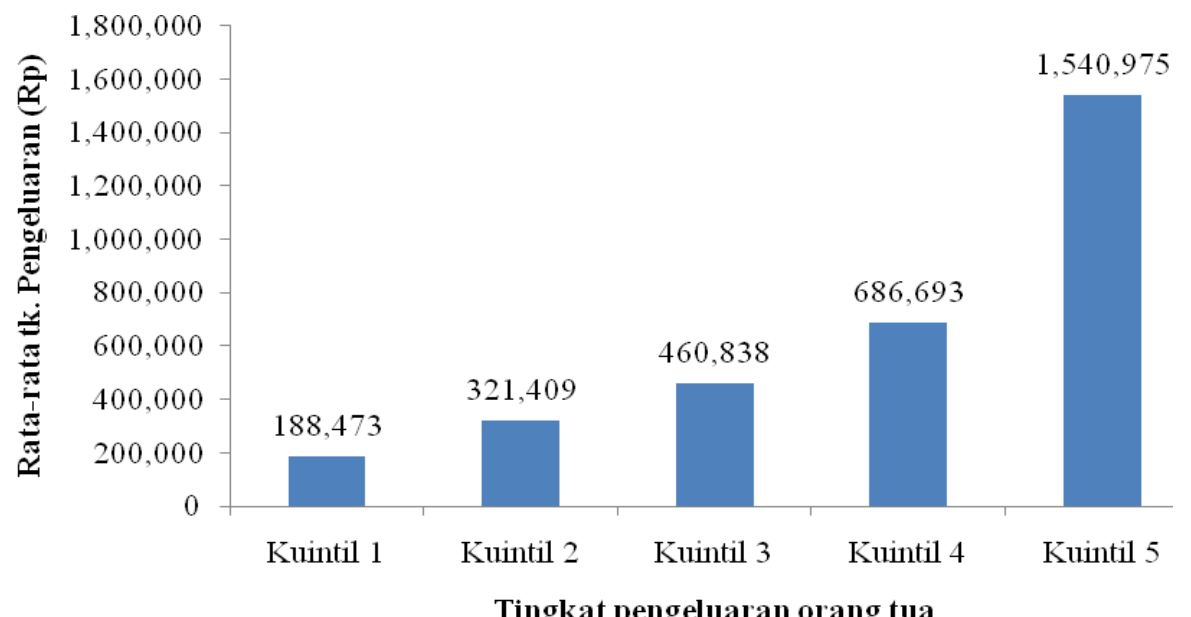

Gambar 8

Rerata tingkat pengeluaran per kapita

Karakteristik penduduk miskin (Gambar 9) dengan jelas dapat pula diamati dari rasio pengeluaran makanan yang cenderung lebih besar, melebihi 60 persen khususnya pada kuintil 1-3, dari total pengeluaran di rumah tangga. Pada kelompok penduduk kuintil 5 , rata-rata pengeluaran makanan kurang dari 50 persen, sedangkan pada kelompok penduduk kuintil 1 , hanya kurang lebih 30 persen pengeluaran untuk kebutuhan lainnya diluar makanan, seperti pendidikan dan kesehatan.

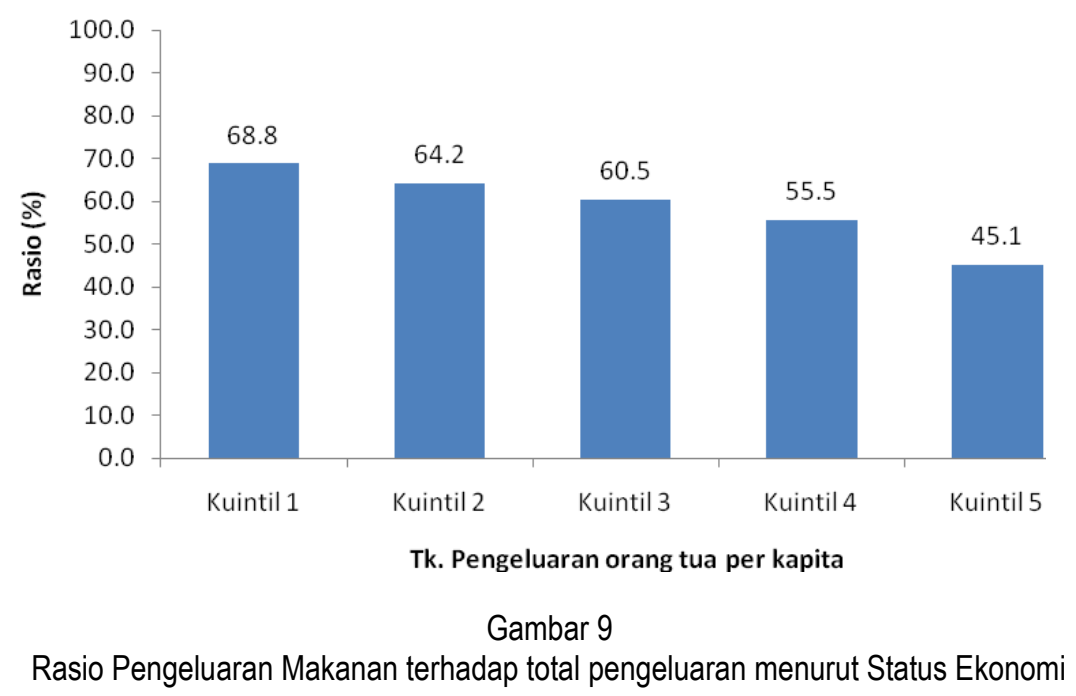

\section{PELAYANAN KESEHATAN YANG DIPEROLEH MASYARAKAT}

Pelayanan kesehatan berkelanjutan kepada masyarakat sangat dibutuhkan untuk memantau dan mencegah kejadian yang tidak diinginkan. Target dari pelayanan kesehatan ini tentunya dianjurkan dapat menjangkau seluruh masyarakat yang ada. Khronisnya masalah gizi yang terjadi di masyarakat, selain penyebab mendasar kemiskinan yang cukup dominan, besar kemungkinan juga disebabkan oleh pelayanan kesehatan 
yang tidak merata, dan juga tidak

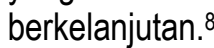

Hasil Riskesdas 2010 menunjukkan cakupan pelayanan kesehatan seperti tercantum pada Tabel 3. Beberapa hal bisa dilihat dari kajian ini antara lain adalah kecenderungan pelayanan kesehatan pada anak yang ditunjukkan menurut kelompok umur. Pada kelompok umur 0-11 bulan dapat menggambarkan kondisi pelayanan kesehatan yang diberikan pada bayi waktu mereka dilahirkan tahun 2009/2010, mengingat pengumpulan data Riskesdas 2010 dilakukan pada bulan Mei-Juli 2010. Demikian seterusnya kelompok anak 48-59 bulan bisa menunjukkan kondisi pelayanan kesehatan lima tahun yang lalu (2005/2006), ketika mereka dilahirkan. Selanjutnya Tabel 3 ini juga menunjukkan perbedaan cakupan pelayanan kesehatan yang diperoleh menurut status ekonomi (tingkat pengeluaran per kapita) dari kelompok penduduk kuintil 1 - kuintil 5 . Seluruh analisis menunjukkan perbedaan bermakna $(p=0.000)$.

Dari hasil analisis ini dapat dikatakan bahwa pelayanan kesehatan secara umum sudah cukup baik, walaupun belum menjangkau seluruh masyarakat yang memerlukan pelayanan kesehatan. Penolong persalinan oleh tenaga kesehatan (nakes) sudah mencapai 82,3 persen tahun 2009/2010, akan tetapi terlihat kesenjangan cakupan pelayanan menurut status ekonomi. Pada kuintil 1, penolong persalinan oleh nakes hanya tercakup 70,3 persen dibanding kuintil 5 yang sudah mencapai 93,7 persen. Bayibayi yang lahir ini sudah mempunyai informasi berat badan, mereka ditimbang dalam kurun waktu 48 jam setelah dilahirkan, dan juga sudah menunjukkan kondisi yang baik. Dimana 85,9 persen bayi yang lahir tahun 2009/2010 sudah ditimbang berat badannya, dibanding bayi yang lahir 5 tahun lalu, hanya 78,2 persen.

Permasalahan mulai muncul dalam kurun waktu 28 hari pertama, dengan rendahnya kunjungan neonatus yang dapat dilakukan oleh tenaga kesehatan. Dapat dilihat pada kelompok 0-11 bulan, kunjungan lengkap neonatus ini baru menjangkau kurang dari 30 persen, dan nampaknya dalam kurun waktu lima tahun, gambaran ini tidak jauh berbeda. Demikian halnya pemantauan 6 bulan terakhir yang seharusnya dilakukan setiap bulan (6 kali), terlihat dengan jelas hanya menjangkau 3040 persen balita yang ada. Penduduk dengan status ekonomi rendah (kuintil 1), cenderung mendapatkan pelayanan kesehatan yang lebih rendah dibanding kelompok penduduk dengan status ekonomi teratas (kuintil 5).

Permasalahan lain yang tidak kalah pentingnya adalah imunisasi. Masih cukup tinggi anak usia 12-23 bulan yang seharusnya mendapat imunisasi lengkap. Pada Tabel 3 bisa dilihat imunisasi lengkap baru menjangkau 54,5 persen. Juga terjadi kesenjangan berdasarkan status ekonomi, terutama antara kuintil 1 dan kuintil 5 . Pemberian kapsul vitamin $A$, yang seharusnya mencakup secara universal pada anak usia 6-59 bulan, juga terlihat baru menjangkau 70 persen, dan sangat bervariasi berdasarkan kelompok umur dan status ekonomi.

Uraian di atas menunjukkan belum terjadinya kesinambungan pelayanan kesehatan yang seharusnya diberikan, khususnya pada anak balita. Hal ini menyebabkan anak mengalami masalah kesehatan dan gizi yang tidak dapat dicegah secara dini. Secara kumulatif kejadian ini bisa menyebabkan khronisnya masalah gizi pada anak. 
Tabel 3

Persentase Cakupan Pelayanan Kesehatan menurut Kelompok Umur dan Status Ekonomi, Riskesdas 2010

\begin{tabular}{|c|c|c|c|c|c|c|}
\hline \multirow{2}{*}{$\begin{array}{c}\text { Yankes/Kelompok } \\
\text { Umur }\end{array}$} & \multicolumn{5}{|c|}{ Status Ekonomi } & \multirow[t]{2}{*}{ Total } \\
\hline & Kuintil1 & Kuintil 2 & Kuintil 3 & Kuintil 4 & Kuintil 5 & \\
\hline \multicolumn{7}{|c|}{ Penolong Persalinan oleh Nakes } \\
\hline $0-11$ bulan & 70,3 & 79,5 & 87,2 & 89,7 & 93,7 & 82.5 \\
\hline $12-23$ bulan & 67,0 & 78,2 & 85,0 & 91,4 & 96,2 & 81.0 \\
\hline 24-35 bulan & 68,8 & 76,1 & 84,7 & 90,3 & 94,9 & 80.9 \\
\hline $36-47$ bulan & 66,2 & 74,0 & 83,3 & 89,1 & 94,5 & 79.5 \\
\hline 48-59 bulan & 66,8 & 74,8 & 81,5 & 89,1 & 94,6 & 79.3 \\
\hline \multicolumn{7}{|c|}{ Kunjungan Neonatus Lengkap (6-48 jam s/d 28 hari) } \\
\hline $0-11$ bulan & 19,2 & 21,4 & 27,6 & 29,1 & 41,1 & 26.2 \\
\hline $12-23$ bulan & 19,2 & 24,4 & 28,8 & 32,2 & 40,3 & 27.2 \\
\hline 24-35 bulan & 17,6 & 23,4 & 25,2 & 33,1 & 35,8 & 25.6 \\
\hline $36-47$ bulan & 16,9 & 23,1 & 25,8 & 33,0 & 42,3 & 26.5 \\
\hline 48-59 bulan & 16,2 & 22,2 & 25,6 & 29,9 & 41,3 & 25.4 \\
\hline \multicolumn{7}{|c|}{ Ditimbang berat badan dalam kurun waktu 48 jam pertama } \\
\hline $0-11$ bulan & 75,3 & 83,5 & 90,3 & 92,4 & 94,5 & 85,9 \\
\hline $12-23$ bulan & 72,5 & 82,8 & 87,8 & 91,6 & 95,4 & 84,1 \\
\hline 24-35 bulan & 70,1 & 80,1 & 87,1 & 90,7 & 93,7 & 82,6 \\
\hline $36-47$ bulan & 66,8 & 75,6 & 83,6 & 91,4 & 92,9 & 80,2 \\
\hline 48-59 bulan & 64,6 & 74,3 & 82,1 & 86,8 & 93,7 & 78,2 \\
\hline \multicolumn{7}{|c|}{ Memiliki KMS/Buku KIA/Catatan Kesehatan Lainnya } \\
\hline $0-11$ bulan & 53,3 & 63,0 & 71,6 & 70,9 & 71,2 & 64,8 \\
\hline 12-23 bulan & 43,1 & 50,1 & 51,6 & 54,0 & 53,5 & 49,6 \\
\hline 24-35 bulan & 26,0 & 34,3 & 35,9 & 35,9 & 34,8 & 32,8 \\
\hline $36-47$ bulan & 21,7 & 25,4 & 27,0 & 25,2 & 28,9 & 25,2 \\
\hline 48-59 bulan & 16,6 & 21,4 & 21,6 & 19,2 & 18,1 & 19,3 \\
\hline \multicolumn{7}{|c|}{ Pemantauan pertumbuhan 6 bulan terakhir } \\
\hline \multicolumn{7}{|l|}{ Tidak Pernah } \\
\hline $0-11$ bulan & 13,6 & 11,4 & 8,8 & 8,2 & 5,4 & 10.0 \\
\hline 12-23 bulan & 23,9 & 21,9 & 20,1 & 18,7 & 16,8 & 20.8 \\
\hline 24-35 bulan & 23,9 & 21,9 & 20,1 & 18,7 & 16,8 & 20.8 \\
\hline $36-47$ bulan & 27,5 & 25,9 & 22,8 & 21,4 & 19,3 & 23.9 \\
\hline 48-59 bulan & 32,1 & 30,1 & 28,2 & 25,7 & 19,2 & 27.9 \\
\hline \multicolumn{7}{|l|}{6 kali } \\
\hline $0-11$ bulan & 25,9 & 32,9 & 26,3 & 30,0 & 28,7 & 28,7 \\
\hline $12-23$ bulan & 34,1 & 35,4 & 40,1 & 34,4 & 33,5 & 35,7 \\
\hline 24-35 bulan & 27,4 & 31,8 & 33,1 & 29,9 & 32,2 & 30,6 \\
\hline $36-47$ bulan & 24,5 & 29,1 & 30,2 & 28,9 & 28,0 & 28,0 \\
\hline 48-59 bulan & 19,6 & 24,8 & 23,0 & 26,5 & 29,0 & 23,9 \\
\hline \multicolumn{7}{|c|}{ Imunisasi pada Anak $12-23$ bulan } \\
\hline Lengkap & 44,6 & 51,4 & 59,1 & 61,1 & 65,0 & 54,5 \\
\hline Tidak lengkap & 36,5 & 37,5 & 30,9 & 29,5 & 31,9 & 33,8 \\
\hline Tidak sama sekali & 19,0 & 11,1 & 9,9 & 9.4 & 3,2 & 11,7 \\
\hline \multicolumn{7}{|c|}{ Mendapat kapsul Vitamin A 6 bulan terakhir } \\
\hline $0-11$ bulan & 40,6 & 37,1 & 36,0 & 37,7 & 37,4 & 37,9 \\
\hline 12-23 bulan & 64,6 & 70,4 & 75,7 & 73,8 & 74,8 & 71,0 \\
\hline 24-35 bulan & 58,9 & 67,4 & 71,9 & 71,8 & 72,4 & 67,5 \\
\hline $36-47$ bulan & 57,8 & 63,8 & 67,9 & 69,8 & 68,4 & 64,8 \\
\hline 48-59 bulan & 53,4 & 60,5 & 61,1 & 62,3 & 66,9 & 60,0 \\
\hline
\end{tabular}

Uji kemaknaan: $p=0.000$ 


\section{FAKTOR LAIN YANG MEMPERBURUK MASALAH GIZI}

Selain masalah cakupan pelayanan kesehatan seperti uraian di atas, faktor lain yang memperburuk keadaan gizi pada anak balita antara lain intake konsumsi yang tidak memenuhi kebutuhan, lahir dengan berat badan rendah, kebiasaan orang tua yang merokok, ibu menikah pada usia yang masih muda, banyaknya anggota rumah tangga dalam rumah, dan beberapa kondisi lainnya seperti sanitasi yang tidak layak, dan lain-lain.

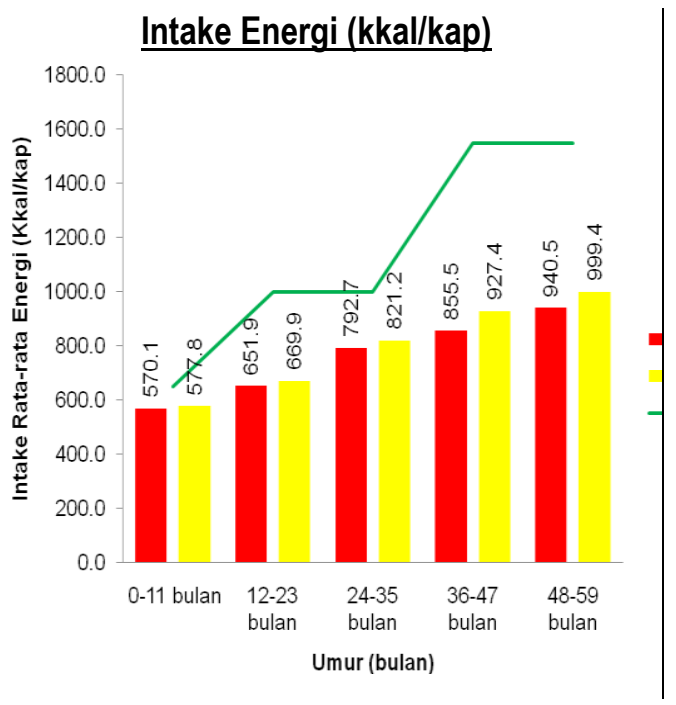

Kecukupan energi dan protein per hari per kapita anak Indonesia terlihat sangat kurang jika dibanding Angka Kecukupan Gizi (AKG) yang dianjurkan baik pada anak normal atau pendek (Gambar 10). Hal ini sangat menarik, ternyata intake energi maupun protein tidak berbeda bermakna antara anak-anak yang tergolong pendek atau normal. Diasumsikan secara umum, konsumsi yang diperoleh untuk seluruh anak (pendek atau normal), kondisinya sama, kurang dari AKG. Kekhronisan terjadi jika masalah ini berlangsung bertahun-tahun.

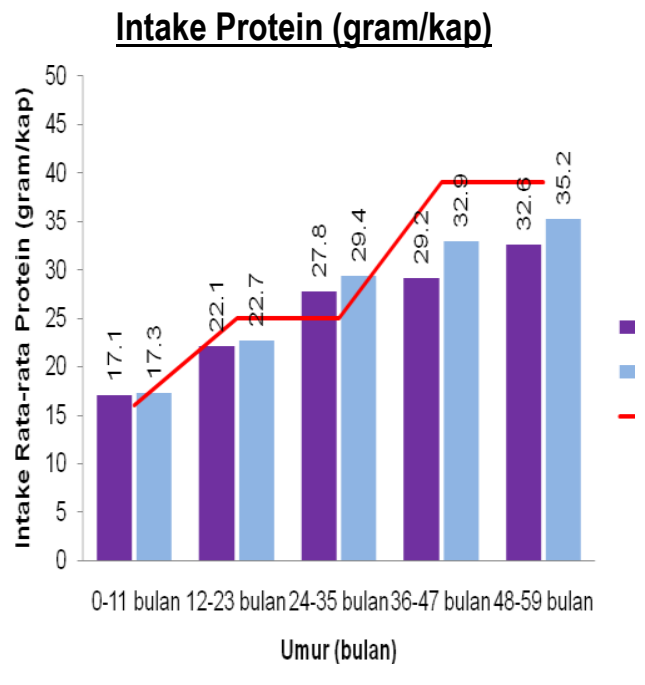

Gambar 10

Rata-rata Intake Energi dan Protein per hari per kapita menurut Umur Anak Balita

Pada Gambar 11, bisa dilihat pada anak-anak yang berat badan waktu lahir $<2500$ gram, cenderung prevalensi kurang gizinya lebih tinggi pada anak yang lahir normal. Pencegahan BBLR menjadi sangat penting, agar status gizi bisa menjadi lebih baik, agar prevalensi kurang gizi bisa lebih rendah.

Faktor yang sangat bermakna memperburuk masalah gizi dengan jelas diperlihatkan pada Gambar 12. Pengaruh orang tua yang merokok baik pada tingkat pengeluaran terendah (kuintil 1) sampai yang teratas (kuintil 5), membedakan besarnya masalah pendek sampai lebih dari dua kali lipat. Pada kelompok termiskin (kuintil 1), prevalensi anak pendek dari orang tua merokok adalah 33,7 persen dibanding yang tidak merokok 13,7 persen.

Prevalensi anak pendek untuk kelompok kuintil 5 juga berbeda mencolok pada orang tua yang merokok atau tidak $(18,1 \%$ dan $9,9 \%)$. Jelas terlihat faktor kemiskinan sangat berpengaruh pada angka prevalensi pendek dan angka ini diperburuk dengan orang tua yang merokok. Secara keseluruhan, orang tua merokok menyebabkan penambahan sekitar 16 persen (OR: 1,156, 95Cl: 1,154; 1.159) kejadian anak pendek dibanding orang tua tidak merokok. 


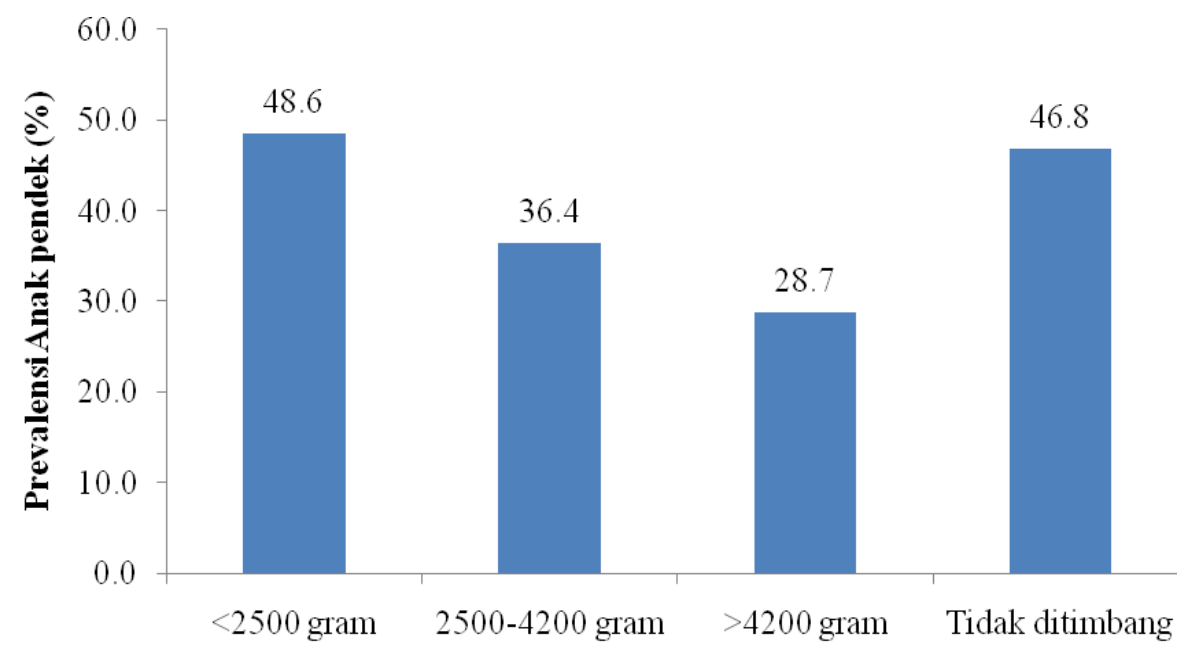

Berat badan lahir

Gambar 11

Persen Status Gizi Anak Balita menurut Berat Badan Lahir

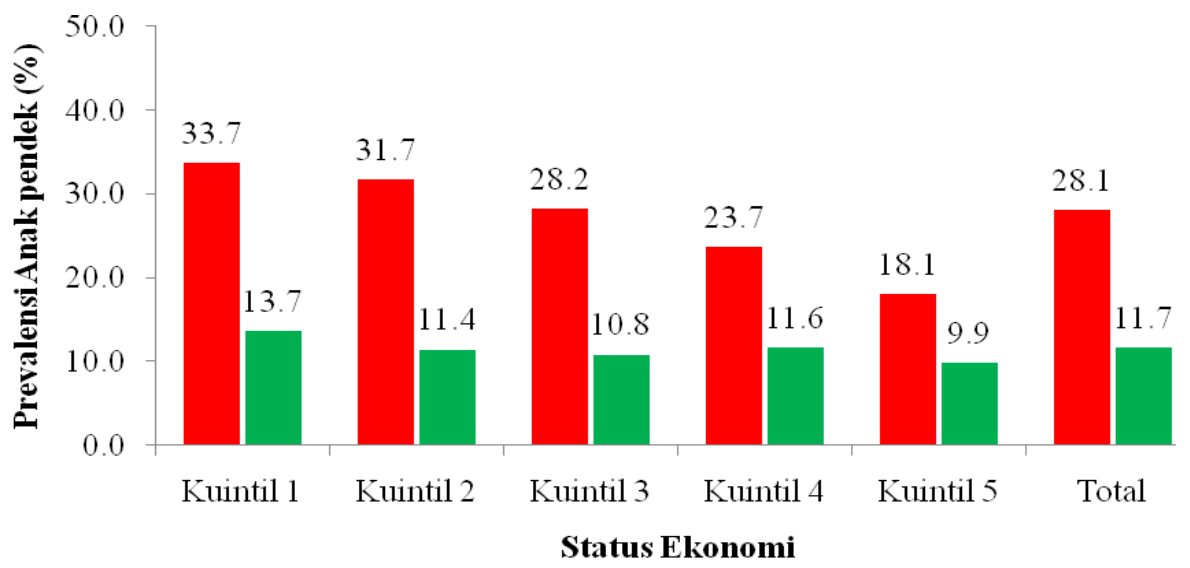

- Ya Merokok $\quad$ Tidak Merokok

Gambar 12

Persen Anak Pendek menurut Merokok/Tidak \& Tingkat Pengeluaran Orang Tua

Faktor yang memperburuk masalah pendek lainnya yang juga sangat penting adalah penundaan usia pernikahan. ${ }^{10}$ Persentase perempuan menikah sebelum menginjak usia 20 tahun cukup tinggi. Dari Riskesdas 2010, diketahui dari kelompok perempuan usia 10-59 tahun yang berstatus menikah, 41,9 persen menikah pada usia 15-19 tahun. Mereka pada umumnya adalah tidak bersekolah/tidak tamat SD. Pada Gambar 13, dengan jelas dapat dilihat bahwa pada kelompok lbu yang sudah menikah di usia 15-19 tahun, pravelensi anak pendek mencapai 42,8 persen, dibanding kelompok lbu yang menikah usia 25-29 tahun $(34,5 \%)$. 


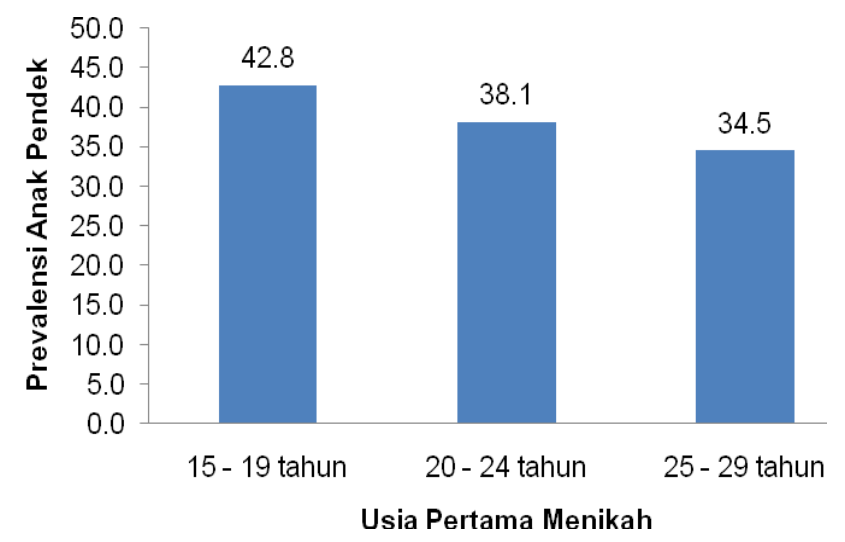

Gambar 13

Prevalensi Anak Pendek menurut Usia Ibu Pertama Menikah

\section{DISPARITAS MASALAH GIZI}

Untuk kepentingan prioritas program, disparitas provinsi untuk prevalensi anak pendek dapat dilihat pada Gambar 14, dan persen BBLR pada Gambar 15. Disparitas cukup lebar antara provinsi dimana prevalensi anak pendek di provinsi NTT mencapai 61,2 persen dibanding provinsi
Kepulauan Riau, yaitu 29,1 persen. Seperti diuraikan sebelumnya anak yang lahir dengan berat badan rendah cenderung status gizinya kurang baik.

Pada Gambar 15, dapat dilihat disparitas angka BBLR menurut provinsi, dari yang tertinggi di Provinsi Kalimantan Selatan $(18,3 \%)$, dan terendah di Maluku Utara $(3,4 \%)$.

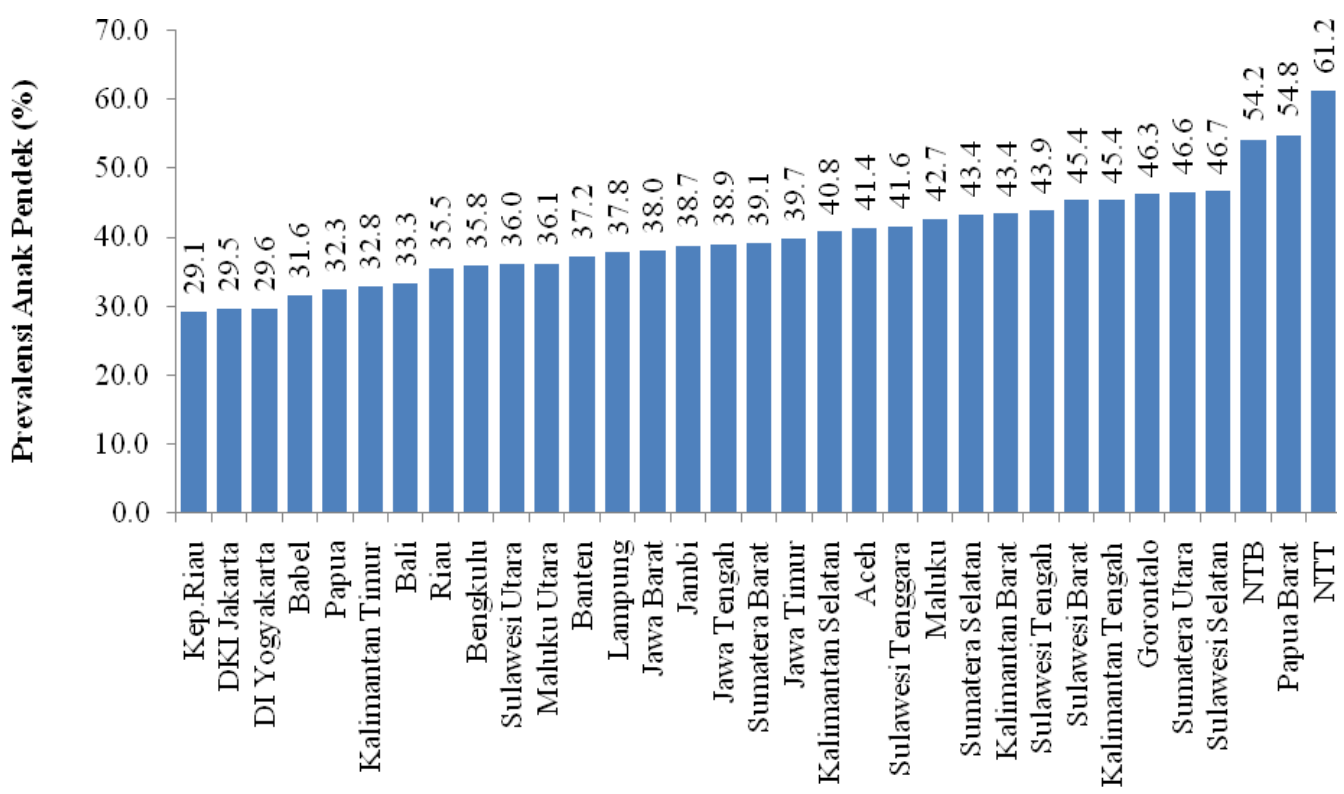

Provinsi

Gambar 14

Prevalensi Anak Pendek (TB/U) menurut Provinsi 


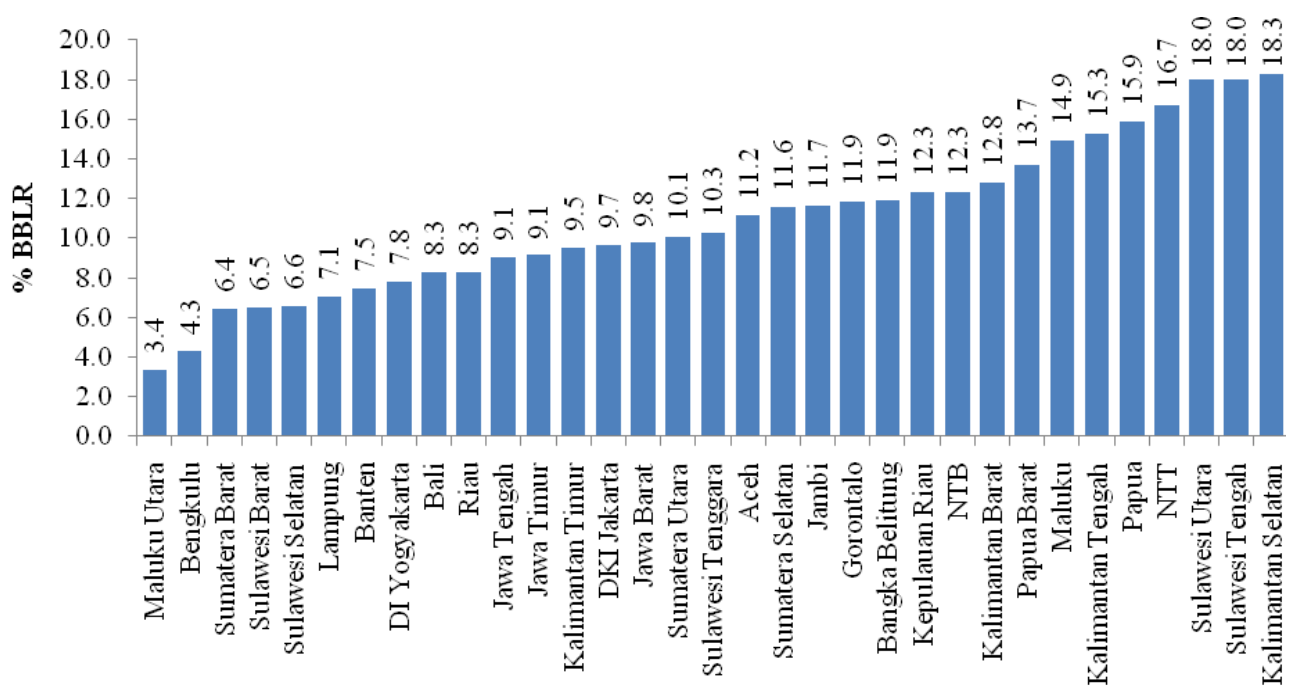

Provinsi

Gambar 15

Persen BBLR Menurut Provinsi

Dengan memperhatikan berbagai faktor yang telah diuraikan sebelumnya, mengurangi disparitas yang lebar antar provinsi dari kedua indikator penting ini seyogyanya dapat dilakukan. Hal ini antara lain melalui peningkatan pelayanan kesehatan, yang tentunya ditujukan pada kelompok penduduk dengan status ekonomi yang kurang beruntung.

\section{SIMPULAN DAN SARAN}

\section{Simpulan}

Kajian di atas menunjukkan berat dan khronisnya masalah gizi di Indonesia. Masalah anak pendek pada balita yang masih dominan diikuti dengan belum tercapainya rata-rata tinggi badan ketika menginjak usia remaja dan dewasa mengindikasikan program pembangunan yang tidak efisien. Jika hasil dari pembangunan yang terintergrasi dari berbagai bidang dapat meningkatkan $1 \mathrm{~cm}$ rata-rata tinggi badan dalam 1 dekade, maka untuk Indonesia dengan melihat kondisi saat ini, perlu waktu minimal 10 dekade agar rata-rata tinggi badan optimal dapat tercapai.

Kerap kali masalah klasik seperti, keberadaan petugas yang tidak memadai, keadaan geografis yang sulit, dan lain sebagainya, dijadikan kendala untuk dapat memberikan pelayanan yang baik untuk masyarakat. Sebenarnya mungkin petugas tersebut juga kurang gizi, mereka kurang mampu untuk memberikan peyuluhan kepada ibu, misalnya tentang konsekuensi yang terjadi jika asupan gizi mikro kurang justru pada saat awal kehamilan. Pengetahuan yang utuh dan baik dari petugas tentang dampak kurang gizi terutama pada kelompok rawan, remaja putri, ibu hamil, bayi dan anak sangat perlu untuk benar-benar dipahami agar dapat disampaikan pula ke masyarakat secara utuh. Selanjutnya, mungkin perlu juga diantisipasi aplikasi dari pengetahuan yang utuh dari petugas tersebut, apakah benarbenar sudah dikondisikan dalam manajemen program yang baik.

Berbagai bentuk intervensi yang dinilai sudah tidak efektif, seharusnya mulai ditinggalkan. Kedepan, Indonesia membutuhkan strategi yang komprehensif dan terintegrasi yang hasilnya dapat terlihat pada perubahan rata-rata tinggi badan manusianya. Investasi dari berbagai bidang untuk meningkatkan keadaan gizi penduduk menjadi suatu keharusan. Upaya pemberdayaan masyarakat menjadi sangat penting. Selain untuk memperbaiki keadaan ekonomi, juga akan membawa masyarakat untuk aktif, minimal mau membawa anaknya ke Posyandu untuk memantau pertumbuhan agar dapat dilakukan intervensi segera jika terlihat 
gejala sangat dini dari gagal tumbuh. Posyandu diharapkan menjadi unit terdepan untuk menggerakkan masyarakat mencapai tujuan tersebut. Dengan demikian integritas Posyandu dan kecerdasan pengelolanya menjadi sangat penting untuk diperhatikan.

Komitmen pemerintah yang diikuti dengan dukungan politik menjadi sangat penting. Visi dan misi yang tertuang dalam RPJPN 2005-2025 perlu dipahami dan diaplikasikan menjadi bentuk program penanggulangan strategis yang dapat merubah dengan cepat kondisi anak Indonesia saat ini. Penilaian program perlu segera dilakukan, terutama merencanakan program penanggulangan yang tidak saling tumpang tindih, mengurangi berbagai bentuk program yang pengalokasiannya hanya untuk pengobatan bukan pencegahan, mulai meningkatkan dan menciptakan upaya yang bersifat proaktif untuk membangun demand masyarakat.

\section{Saran}

Untuk ke depan, jika SDM Indonesia akan ditingkatkan demi kemajuan negara sesuai dengan misi RPJPN 2005-2025, maka beberapa pendekatan atau rekomendasi kebijakan yang perlu dilakukan adalah:

1. Advokasi dan komunikasi

Untuk mencapai komitmen bersama, maka informasi yang komprehensif tentang permasalahan di atas, berikut dengan solusi atau alternatif programnya perlu disampaikan terus menerus keseluruh individu, organisasi, insititusi yang terlibat. Komunikasi yang jelas perlu dilaksanakan atau diaplikasikan untuk membangun komitmen dalam upaya perencanaan progam yang benar bertujuan pada penanggulangan masalah anak pendek.

2. Analisis kebijakan

Analisis kebijakan untuk pengembangan program strategis yang berdasarkan pada informasi yang lengkap mutlak dilakukan. Indonesia yang berpengalaman mengembangkan program perbaikan gizi sudah seharusnya melakukan lagi dengan memperhatikan situasi wilayah dan masyarakat pada saat sekarang. Pengalaman program yang tidak mempunyai daya ungkit seharusnya perlu dinilai kembali. Analisis perbedaan wilayah perlu dilakukan untuk pengembangan strategi program yang akan dilaksanakan.

3. Manajemen program

Manajemen pelaksanaan program yang selama ini tidak menjadi pertimbangan perlu mulai diaplikasikan. Mulai dilakukan perhitungan tentang kebutuhan tenaga, unit cost program yang tidak merata, kepemimpinan yang dapat memotivasi dan membangun kreativitas staf, serta terjadinya mekanisme kerja yang efektif agar program berjalan baik.

4. Survailans, Monitoring dan Evaluasi Program

Masalah gizi menjadi khronis disebabkan karena surveilans yang tidak berfungsi. Survailans, monitoring dan evaluasi program sangat diperlukan untuk mengantisipasi berbagai perubahan yang dapat memperburuk situasi di masyarakat. Surveilans ini perlu dilakukan di setiap tingkat administrasi pemerintahan untuk selalu melakukan analisis/kajian yang terus menerus dan menginformasikan hasil analisis ke pelaksana/pimpinan wilayah jika ada yang perlu diambil tindakan segera.

\section{RUJUKAN}

1. Kementerian Kesehatan Rl. Riset Kesehatan Dasar (Riskesdas) 2010. Laporan Penelitian. Jakarta: Badan Litbang Kesehatan; 2010.

2. Departemen Kesehatan RI. Riset Kesehatan Dasar (Riskesdas) Indonesia 2007. Laporan Penelitian. Jakarta: Badan Litbang Kesehatan; 2008.

3. Badan Pusat Statistik. Data Survei Sosial Ekonomi Nasional 2010. Jakarta: BPS; 2011.

4. World Bank. Repositioning Nutrition as Central Development. A Strategy for Large Scale Action. Geneva: World Bank; 2006.

5. de Onis M, et.al. WHO Child Growth Standards. Acta Paediatrica, International Journal of Paediatrics. 2006; 95(April). Supplement 450.

6. World Health Organization. WHO Child Growth Standards: Methods and Development. Geneva: WHO; 2006. 
7. World Health Organization. WHO Child Growth Standards 5-19 years. Geneva: WHO; 2007

8. Beckmann, David, and Emily Byers. Building political will to end Hunger: Bread for the world. Paper prepared for the United Nations Millenium Project Hunger Task Force. Washington D.C.: U.N; 2004.
9. Bhutta Z., Ahmed T., Black R. What works? Interventions for maternal and child undernutrition and survival. Lancet. 2008;371:417-40

10. Black, R., Allen L., Bhutta Z. Maternal and child undernutrition: global and regional exposures and health consequences. Lancet. 2008;371:5-22. 